\title{
CORRELATION BETWEEN BROKEN HOME AND COPING STRATEGY UPON ADOLESCENT PERSONALITY
}

\author{
Aji Bayu Utomo ${ }^{1)}$ Anna Miftakhul Rizky ${ }^{1)}$ Sindi Febriani ${ }^{1)}$ Kharisma Rizky A ${ }^{2)}$ Erna Erawati \\ bayuaji939@gmail.com \\ Semarang Health Polytechnic, DIII Nursing Study Program Magelang \\ Perintis Kemerdekaan Street, North Kramat, Magelang, Central Java
}

\begin{abstract}
Background: Youth from broken home families are very vulnerable because of depression experienced in facing stressful conditions. Each individual will develop a stress management strategy called coping strategy, which have impact on ones personality.

Objective: To obtain empirical data in order to find out the correlation between broken home and coping strategy in adolescents

Method: Thestudy used correlational techniques, data collection in the form of a strategyways of coping coping questionnaire from Lazarus and questionnaire identification of broken family. Data analysis using statistics.

Results:From the statistical results using the Chi-squared contingency coefficient obtained $\mathrm{X}^{2}$ hits of 10.615 and $\mathrm{C}$ of 0.458 . Because the ratio of values $\mathrm{C}=0.458$ and Cmax $=0.707$, based on the norms of contingency shows a sufficient degree of correlation between broken home with coping strategy in Youth Personality at Marsudi Putra Antasena Social Assistance Magelang.

Conclusion:There is a significant correlation between youth age personality Broken home with Coping Strategy in adolescents at Marsudi Putra Antasena Social Assistance Magelang, with moderate levels of correlation
\end{abstract}

Keywords: broken home; coping strategy; adolescent personality

1) Student of Magelang Nursing Department, Poltekkes Kemenkes Semarang

2) Lecturer of Magelang Nursing Department, Poltekkes Kemenkes Semarang

Background. Juvenile delinquency phenomenon already familiar to our ears where the juvenile delinquency is one of them motivated by problems in the family environment that are not normal or often referred to as broken home. Broken home is interpreted as a family condition that is not harmonious and does not work like a harmonious, peaceful, and prosperous family because of frequent riots and disputes that cause fights and end in divorce. From the family described above, children will be born who experience a personality crisis, so their behavior becomes wild. They experience emotional and even neurotic disorders. (Willis, 2008: 66)

We cannot just stand up against these problems, we need to find out what causes them. From the closest things, namely the family environment. Youth are times where there is a transition from childhood to adulthood. In this period someone will start looking for his identity. They will look for someone who is a role model. If the period is experienced by a rama who 
gets a disturbance from his family or a broken home, it will be very vulnerable and difficult because of the depression that they may experience. Moreover, if the youthager is wrong in the association and does not get direction, encouragement, and motivation, he or she will fall into the wrong correlation so that the phenomenon of juvenile delinquency will emerge. Adolescents who do not know how to use and choose strategies are good for use in parental divorce cases, usually these remarks voice their feelings with juvenile delinquency and internal problems such as anxiety and depression. Even the most worrying is the other youth' fears that result in lack of social responsibility, dropping out of school, being sexually active at an early age and using illegal drugs. This is because the youthager cannot accept the real condition that his family has divorced, where his father and mother are no longer united and do not know how to choose the right coping strategy for him (Goode, 1985). With coping strategies that will be chosen by adolescents and strategies chosen by adolescents that are right for solving problems faced by adolescents in divorce cases, parents will increase adolescents' self-acceptance with selfacceptance, the adolescent can accept any circumstances or changes that occur in his family., the youthager is not only resigned and resides with the situation, but he is trying to accept a changing situation in his family so that the youthager feels comfortable with the life he lives now.

Several studies have shown thatfamilies broken homeaffect adolescent personality development. Based on the results of the study, the number of divorces in Samarinda has reached a very fantastic number. Note, in the last 3 years the number of divorce cases has increased, from 2014 to 2016. In 2014, the court of justice received a number of 2,138 cases and in 2015 the Samarinda City Religious Court received 2,063 cases. The most drastic case numbers are in 2016 The Religious Court of Samarinda City has received 2,310 cases. Further explained by Marieke van de Rakt through her research results that "Every year a youthager has a chance of about $1 \%$ to do something that is not good. that possibility has tripled, in other words, a youthager has a $3 \%$ chance to do something that is not good, the cause is a variety of factors, but clearly, a divorce has an impact on the life of a household due to an atmosphere that is not peaceful, emotional adolescents are often disturbed, someone who is initially cheerful, open, and easy to get along with will turn into moody, lazy, dishonest and even rebellious when there is a problem with the family, for example both parents divorce or one of them dies and lack of compassion old given to adolescents, so that youths feel palpable fish in the family. (Muklhis Aziz, 2015).

This study research is about the personality of adolescents who get youth age problems broken home so they can know and understand how the right coping strategies for adolescents "broken home" are located at Marsudi Putra Social Assistance in Magelang, which has a role to provide guidance, service and social rehabilitation that is pre-emptive, curative, rehabilitative, promotion in the form of physical, mental, social guidance and skills training, resocialization and advanced guidance for adolescents who behave deviant in order to be able to be 
independent and play an active role in community life and review and prepare service and referral standards.

Objective. The aim of this research is to know the correlation between broken home with giving coping strategy on adolescents personality. The type of this study is an analytical survey.

Methods. Analytical surveys try to explore how and why the phenomenon broken home occurs, then analyze the dynamics of correlation between phenomena or between risk factors and effect factors. Variables in this studies are history of broken home adolescents and coping strategy using chi square. The study conducted at the Marsudi Putra Antasena Social Assistance Magelang found 40 respondents who met the inclusion and exclusion criteria and were willing to follow research. During the implementation of the intervention using the coping strategy questionnaire there was no respondents dropped out.

\section{Result and discussion}

Table 1. Frequency and PercentageofBroken Home and Coping Strategy

\begin{tabular}{cccccccc}
\hline \multirow{2}{*}{$\begin{array}{c}\text { Broken } \\
\text { home }\end{array}$} & \multicolumn{3}{c}{ Coping strategy } & \multicolumn{2}{c}{ Total } \\
\cline { 2 - 6 } & Problems & \multicolumn{2}{c}{ Emotional } & & \\
\cline { 2 - 6 } & $\mathrm{F}$ & $\%$ & $\mathrm{~F}$ & $\%$ & $\mathrm{~F}$ & $\%$ \\
\hline Negative & 15 & 37 & 7 & 17 & 22 & 55 \\
\hline Positive & 3 & 7.5 & 15 & 37.5 & 18 & 45 \\
\hline Total & 18 & 45 & 22 & 55 & 40 & 100 \\
\hline
\end{tabular}

Table 2. Frequency and Percentage Coping Strategy on Youths Coping Strategy

\begin{tabular}{lllc}
\hline \multicolumn{1}{c}{ Indicator } & \multicolumn{1}{c}{ Subindicator } & F & $\%$ \\
\hline $\begin{array}{l}\text { Problem } \\
\text { focused } \\
\text { coping }\end{array}$ & Confrontative coping & - & - \\
\cline { 2 - 4 } & Plan problem solving & 3 & 16.66 \\
\hline $\begin{array}{l}\text { Emotion } \\
\text { focused }\end{array}$ & Distance & 1 & 5.56 \\
\hline
\end{tabular}

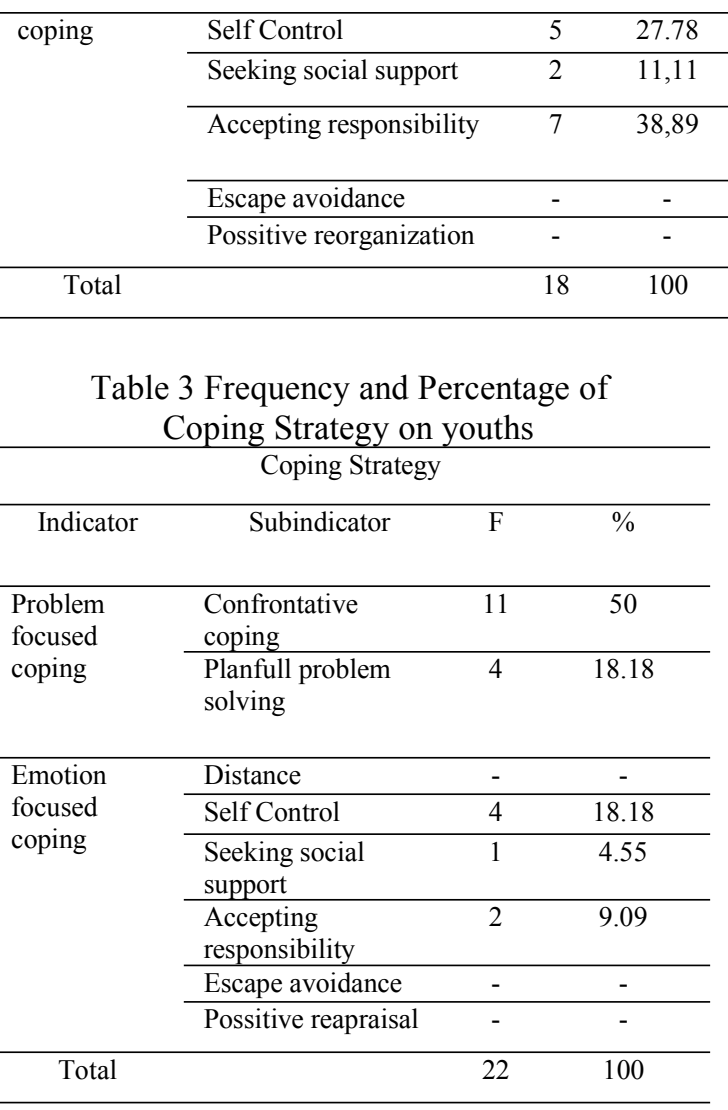

Tabel 4. Broken Home Contingency with Coping Strategy in Youth Personality

\begin{tabular}{cccccc}
\hline & \multicolumn{4}{c}{ Coping strategy } & \multirow{2}{*}{ Total } \\
\cline { 2 - 5 } $\begin{array}{c}\text { Broken } \\
\text { home }\end{array}$ & \multicolumn{3}{c}{ Problems } & \multicolumn{2}{c}{ Emotion } \\
\cline { 2 - 5 } & Oij & Eij & Oij & Eij & F \\
\hline No & 15 & 9.9 & 7 & 12.1 & 22 \\
\hline Yes & 3 & 8.1 & 15 & 9.9 & 18 \\
\hline Total & & 18 & & 22 & 40 \\
\hline
\end{tabular}

\section{Results}

Results of the statistics by using the Chi-square contingency coefficient obtained $\mathrm{X}^{2}$ hit amounted to 10615 , Cmax $=0.707$ and $\mathrm{C}$ of 0458 .

Because the value of $\mathrm{C}=0.458$ is obtained, based on the contingency norms, there is a sufficient correlation between broken home and coping strategy in the Youth Personality at Marsudi Putra Antasena Social Assistance, Magelang. 


\section{Discussion}

Based on the results of data processing using the chi-square contingency coefficient calculation in the study conducted on adolescents who experienced problems with broken home and coping strategy on them. From the correlation calculation using the chi squared contingency coefficient between broken home and coping strategyand based on thetable, the Guilfordvalues included in the criteria for moderate correlation are obtained. It can be said that the problem of broken home has a significant importance in the selection of the use of coping strategies that will be used by youth in the Marsudi Putra Antasena Social Assistance Magelang.

Table 3 lists 22 adolescents who have a history of broken home negatives. Of the 22 people who have a history of broken home negatives, 15 of them used coping strategiesthat centered on problems in overcoming various demands. According to Lazarus and Folkman (1984: 150) a problemcentered coping strategy will be chosen by individuals if the individual judges that the stressor can be changed. In the correlation table the frequency of percentage of coping strategies in adolescents with a history of negative home brokenness (Table 3), there are $50 \%$ of adolescents who have a history of broken home negatives tend to use coping strategies in the form of confrontative coping. Confrontative coping is defined as a problem coping strategy that better describes one's aggressiveness and risk taking which is reflected in phenomena, they make an effort to solve problems more effectively. From the data obtained and attached to table 3 They are individuals who have confidence that situations or problems that cause stress can be changed by using the resources and capabilities they have. They are more concerned with the problems they face as a lesson or something that is positive compared to seeing the problem as a burden.

In table 2 it is known that there are 18 adolescents with a history of broken home positives. Of the 18 people who have a history of broken home negatives, 15 of them used a form of coping strategy emotionalcentered.Fitts (1971) states that broken home has a strong influence on a person's behavior. Thus it can be said that a negative assessment of oneself will influence the judgment and ways of dealing with the stressful situations facing it. In this case because of the negative assessment of the ability, it makes them feel that nothing can be done in the face of stressful conditions. Therefore, when they face problems they only make an effort to reduce the pressure they experience. As shown in Table 3 of the frequency and percentage of coping strategies in adolescents with a history of broken home negatives, the methods used by adolescents with a history of broken home in reducing pressure include excape avoidance, accepting responsability, positive reappraisance and distance. From the data obtained and attached to table 3 , in general they see the problems faced as a burden or something more negative. Besides having a negative view of a problem faced, it also shows that they are not very active in gathering in the environment. people thus lack the ability to communicate and act in appropriate and effective ways in their social environment so that they are less 
likely to gain cooperation and support from others.

As Fitts explained (1971: 23) that the individual's way of looking at and appreciating himself will give color or influence his view of the situation he is facing. Individuals who have a history of broken home positivity appear to have a positive outlook in responding to the various problems they face. However, in this study as shown in table 2, there were 18 adolescents with a history of broken home positive 7 of them using coping strategy an emotion-centeredthat is accepting responsability. According to Lazarus and Folkman (1984) there are several things that support a person in do coping strategy. one of them is the skill in solving problems. problem solving skills in the form of the ability to find information, analyze situations, identify problems as an effort to find alternative actions, consider them, choose and implement the right plan in acting to solve the problem. While the skills to solve problems according to Janis and Mann (Muniroh Abdurrachman, 1999) are obtained through extensive experience, knowledge possessed and intellectual / cognitive abilities to use that knowledge. Adolescents with a history of broken home negatives with low academic demands and unfamiliar with the demands of their associates will have less experience in dealing with stressful situations when compared to youth with a history of broken home negatives with high academic demands and getting used to associations.

Based on Table 2, 3 people from 18 people with a history of broken home negatives chose to use a problemcoping strategy -centered. In the correlation table the frequency and percentage of coping strategy in adolescents with a history of broken home negative table 2 there were 3 people or $16.67 \%$ of the total adolescents with a history of broken home negatives tend to use coping strategies in the form of planful problem solving. In the phenomenon of 3 adolescents who have a history of broken home negatively showing behavior often try to plan a plan and try to share time well about everything related to the demands of the demands. Lazarus and Folkman (1984: 159-164) Suggests that social support in the form of emotional support or in the form of real information and support and the existence of material resources, namely money or in kind can provide important contributions to someone using the coping strategy he does. the statement above, gives a great possibility that even though adolescents with a history of broken home are positive but with emotional support, information support, real support and sources of material resources, adolescents with broken home history can use problemcoping strategies -centered.

Conclusion and Suggestions. Based on the results obtained from data processing and discussion, as well as hypothesis testing carried out using statistical methods, then from this study it can be concluded that:

1. There is a significant correlation between youthage personality Broken home with Coping Strategy in adolescents at Marsudi Putra Antasena Social Assistance Magelang, with a moderate level of correlation.

2. The use of coping strategies emotion-centeredis more often used on the personality of adolescents 
who have a tendency to experience broken home as many as 18 people. Of the 18 people, 3 people chose to use a problem-centered stress management strategy and 15 people centered on emotions. The use of emotional centered coping strategies is more often used in adolescents broken home positive because of adolescenceuse more emotions to reduce stress, by changing the meaning of the situation. This strategy is the same as reappraisal. Not allrevaluation isin nature defensive and directed at regulating emotions.

3. The use of coping strategies that are problem-centered is more often used on the personality of adolescents who have a tendency not to experience broken homes as many as 22 people. Of these 22 people, 15 people chose to use a problemcentered stress management strategy and 7 people centered on emotions. The use of coping strategies centered on problems more often used by youth broken home negatively because youth broken home more often regulate or change problems that cause pressures, obstacles, source sources, environmental procedures or individuals such as changing the level of aspirations, looking for other ways to satisfy and learn new skills.

Given that problem-solving skills is useful for Youth who Broken home and copingstrategy, it is for youth Marsudi Putra Antasena Social Assistance Magelang. Another youthager is expected to be active in following the activities and types of training to be able to control emotions and problems with thoughtful.

\section{References}

Ahyar, 2010. Koping mechanism, psychology. Jakarta: Yogyakarta: Ministry of Education and Culture.

Azwar, Saifuddin (2009), Reliability and Validity, Student Library, Yogyakarta.

Matinka, 2011.Broken home impact on child care patterns.http://repository.usu.ac.id/ bitstream/handle/123456789/2692 3/Reference.article;jsessionid $=901$ 7B3474243427C5467F3A01A801 660 ? sequence $=2($ January 12,2018$)$

Mukhlis Aziz, 2015. Social behavior of adolescent children victims of broken home in various perspectives.http://download.portal garuda.org/article.php?article $=359$ $\underline{004 \& \mathrm{val}=8240}($ September 12 , 2018)

Naughton, O. Fumi. Stress and Coping,http://www.csun.edu/ cps y00h/students/coping.htm (Sep. 12, 2018)

Revelation Sri Putri AR, 2012. Forgive Behavior Among Youths Broken Home.http:

//download.portalgaruda.org/article. php? article $=123316 \&$ val $=5545 .(10$ September 2018)

Robertus Belarmino Umbu Kaballu, 2014. Broken Home Open Questionnaire.University of Soegija Pranata http://repository.unika.ac.id/990/7/ 06.40.0240\%20Robertus\%20Belar mino\%20Umbu\%20Kaballu\%20L AMPIRAN.pdf

Syarifatinisnaini, 2014 Self-Efficacy on Parents Victims of Divorce Youth.Surakarta:

UMShttp://repository.umy.ac.id/bit stream/handle/123456789/15065/6. $\% 20 \mathrm{BAB} \% 20 \mathrm{II}$.pdf? sequence $=6 \&$ isAllowed $=y($ April 26, 2018) 